\title{
Methodological Basis of the Theoretical and Legal Research of Integration Processes in Modern States
}

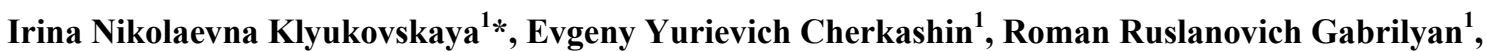 \\ Viktor Yegorovich Semenov ${ }^{1}$, Ruslan Kurmanovich Melekayev ${ }^{1}$ \\ ${ }^{1}$ North-Caucasus Federal University, Pushkin Str., 1, Stavropol, 355009, Russia \\ *Corresponding author E-mail: klyukovskaya.i.n@mail.ru
}

\begin{abstract}
This article specifies theoretical globalization-related problems that require more detailed and scrupulous consideration. The study defines the objectivity of teleological processes, factors affecting their course and forms established under their influence. The authors analyze methodological proofs of global integration processes in the modern world. Using dialectical, historical-legal and comparativelegal research methods, the authors have determined circumstances forming various types of globalization, ways to resolve globalizationcaused conflicts through the common-cause factor (optimization through the recognition and declaration of goals and their underlying values) or the institutional system of formal and actual dominants that structures the international hierarchy of states and defines power poles.

The scientific novelty of this study consists in the analysis of objective globalization-related problems regardless of propagandist and ideological stereotypes from the viewpoint of scientific pragmatism and formal-logical rules.
\end{abstract}

Keywords: Integration processes, new globalism, international relations, world-system theory, conflicts, sovereignty, international law.

\section{Introduction}

At the current period of historical development of civilization, the international legal practice does not have a more controversial issue than global integration, as well as the related to it objective need, directions of its manifestation and methods of its legitimization.

This trend can be explained by theoretical mistakes in defining the correlation between public interests and individual-state needs characterized by national-mental and economic-mental characteristics, as well as the degree of state self-identification with unquestionably emotional-propagandistic overstatement and sometimes understatement of their significance in any given international events and actions [1].

To dwell on the stated problem, it is necessary to determine the research subject from the methodological perspective. According to most scholars considering this scientific issue, the "integration" concept cannot be analyzed regardless of all the components of globalization as a kind of hyperintegration. At the same time, it is impossible to distinguish unconditional dominants of this movement. They change due to stable or permanent determinants of objective and subjective dependence [2].

The vital activity of modern peoples and states in the context of integration needs and their possible directions is characterized by a strong influence of two opposite tendencies: economic-political integration and people's differentiation, which ensure the coherent formation of society only in case of their relative balance.

Rapidly changing relations between different ethnic groups and the transformation of the long-established ethnic differentiation of humankind allowed some scholars to talk about the so-called ethnic revolution [3].
Economic-political integration is determined by scientific and technological revolution and global changes, which lead to the destruction of state barriers and the internationalization of social life. This trend is intertwined with the counter-trend of people's differentiation, the formation of people's communities, the increase of state self-cognition and the aggravation of interethnic contradictions.

At this stage of governmental and international formation, interethnic contradictions quite often escalate to the level of armed conflicts that acquire a global character and hinder the natural formation of the newest ethnoses - superethnoses due to socially consolidating factors (mainly religious). The state factor and some others are less important for the above-mentioned ethnoses.

\section{Methods}

The methodological basis of this study comprises a wide range of modern research methods, including general scientific, specific scientific, quantitative and qualitative methods. This vast base is used since one approach is insufficient to achieve the set goal in studying such a complex phenomenon as global integration. The main research methods are historical-legal and comparative jurisprudence.

The historical-legal method aims to study both national and international legal phenomena retrospectively. It fulfills an important prognostic function and uses historical factors predetermining the formation of linear integration processes to predict globalization trends in the future. The study uses both synchronic and diachronic methods of comparative jurisprudence which, together with the historical method, improve the research of global integration processes (a significant sphere of international legal reality). 


\section{Results}

The circumstances described in the introduction emphasize the problem of the so-called "insulted people". These "insults" are as follows:

1.Historical "insults". Peoples were "excluded" from the formation of their countries and played a secondary role of "public extras" in the course of their own historical development. This trend can be exemplified by small peoples of the Russian North.

2. Military "insults". This trend mainly refers to peoples who were forcibly annexed to Russia. While analyzing this phenomenon, the authors of the article have noticed that this factor was quite promising for many of them. Even if people were forcedly integrated into the more developed all-Russian market and joined more sophisticated social, socio-political and financial relations, this process induced both socially and financially progressive movements.

3. National and political "insults" of repressed peoples. In this case, such a progressive phenomenon as the state memory (the oral transmission of accumulated experience and local-state events) serves as a trigger of state hostility and public-state conflicts for the entire nation forming the national-social dominant in contrast to specific individuals or a group of persons who made this decision and realized it.

The orientation of economic and political integration is activated by two key factors - economic and scientific-technological progress. Their mutual ties embrace the whole world and the life activity of global society. Due to this growing interdependence, the world economy as a concept becomes more and more integrated. The financial foundation of this concept was laid by international companies. Transnational corporations are big companies that have become the driving force for internationalizing the global economy. It means that hundreds of dominant companies establish the economic ratio between sales and production. In this case, corporations are involved not only in the economic sphere of life but also in politics [4]. In general, transnational corporations control about $50 \%$ of the world industrial production. These companies account for more than $70 \%$ of global trade. About $40 \%$ of deals are made inside transnational corporations. Their trade activity is conducted not at market value but rather at transfer value. This value is created by the policy of the main company. The indicator of this process is the dynamic growth of value. From 2002 to 2012, the annual turnover of 200 largest companies increased from 3,000 to 59,000 billion US dollars, and their share in gross domestic product reached $27 \%$. This is roughly equal to the annual production of the United States. Transnational corporations form the essence of the so-called "world order". In 2018, the annual turnover of the top 10 companies has accounted for 2.7 trillion US dollars [5].

Similar trends take place in other spheres of the world community. The role and influence of global and regional structures also increase as they coordinate social, financial, socio-political and other spheres of life activity.

The above-mentioned trends demonstrate that economic-political integration leads modern peoples and countries to the greatest rapprochement at numerous levels. On the one hand, this unification originates at the economic-political level and does not consider the national characteristics of different peoples and countries. On the other hand, the process proclaims the dignity of individualism, liberalism, equal rights and human freedoms, democracy, constitutionalism, the rule of law, etc., and the formation of a global culture based on universal values (Western values). This peculiarity of rapprochement (the opposition of the West and the rest of the world) poses a serious threat as it can result in a severe confrontation between different ethnic groups and play a fatal role in human history.

However, the authors of this article would like to dwell on the legal aspect of globalization, while having in mind law as a general concept of international regulatory and global consensual absolutes. Special attention is paid to the internationalization and negative integration of unlawful phenomena typical of almost all national-social and international innovative procedures that do not have developed implementation methods.

Legal integration concerns not only different spheres of government administration but also the field of state protection. The first notion that requires clarification and methodological definition is "government sovereignty". The classical definition of sovereignty given in the concept of state and law as absolute independence, territorial integrity and unacceptability of any kind of interference in the development and implementation of government decisions [6] may seem to be seriously outdated due to events of the past two decades. Taking into account international legal realities, the authors believe it is most appropriate to divide government sovereignty into two interrelated parts. The first part is internal sovereignty, and the abovementioned definition can be applied to it. However, the second part should be defined in some other way. External sovereignty is the ability and opportunity to fully participate in the work of international legal institutions, pacts and treaties in an equitable manner.

It should also be noted that each concept equalizes and absolutizes humanitarian values in different ways but vies for systemic or ideological primacy. Furthermore, the selection of tools to achieve this leadership is determined only by the historical experience and socio-political traditions of any given state-candidate. In addition, one of the key problems is to determine the benefitor of such integration. In fact, most benefits are acquired by wealthy states or individuals. The unequal allocation of benefits received from the integration of knowingly unequal actors can lead to regional, national and international conflicts. Thus, there is a need for an adequate strategy to counteract multiple negative aspects of integration, as well as its threats and "challenges" [2].

This process should be analyzed with regard to the conformity of international powers and state powers of particular globalization actors. The modern concept of powers highlights global trends in the formation and development of international law. It is the evergrowing importance of international law in the life of civilization and the survival method of people as a biological species and a unique public community [7].

There are two large structures of international law: public and individual. They have a major influence on political, economic, and personal-legal functions of international law, and increase the significance of international humanitarian law.

Eventually, international law has ceased to be an external notion characterized by special relations with state concepts of law. Now generally accepted principles and norms of international law are being introduced into the state concept of law [8] and heavily influence it.

Along with material norms of international law, its procedural aspect also formed at the turn of the $20^{\text {th }}$ and $21^{\text {st }}$ centuries. It gave rise to numerous procedural instruments aimed to resolve disputes and conflicts (mediation court, arbitration and other judicial bodies) [9]. The international legal process was rapidly developing, including application procedures, international legal proceedings, etc.

Some constitutions state the right of citizens who have used up all the possibilities to solve their problems within the national defense of rights, independence and legitimate interests to apply to the relevant international judicial authorities [10].

Types of influence also acquire international features, including the influence of some groups and states significantly deviating from generally accepted principles and norms of international law (hostility, civil wars, anti-ecological work dangerous for the whole humankind, etc.). In this case, collective financial and military sanctions are chosen as means of ensuring this influence. It is worth mentioning that special military structures are formed to conduct this international legal work, including rapid deployment forces, "blue helmets", etc. International law also acquires "material" characteristics that guarantee its functioning [11]. 
From the theoretical viewpoint, the authors of the article are interested in the formal internationalization of legal norms. As a rule, it is a complex of measures for unifying regulatory conditions by leveling state specifics and classifying legal values in their unification. This process becomes a challenge that calls for an indepth analysis.

For a start, one should define the main principal determinants that determine diverse approaches to the systematization of various characteristics of the process and its desired results. To provide such a definition, one needs to analyze gradually developing relations of domestic production, distribution and exchange, as well as similar processes at the international scale.

According to the general theory of system development, interacting groups have at least two mutually exclusive forces centralization and decentralization. The struggle of these opposite trends determines the objective and rational organization of relations.

At the same time, an objective process does not guarantee predictability, progressive characteristics or results. These features can be guaranteed only by unified norms, standards and scales characterized by universality, general binding nature, the highest degree of assurance, i.e. international legitimacy. These properties are typical of international legal regulators which develop from recognized and declared rational qualities of international relations. The primary stages are characterized by complete absorption with dominant interests and principles of an absorbing actor. This phenomenon is considered within the world-system theory. This theory explores the evolution of social systems rather than individual societies. This approach was first introduced by Andre Gunder Frank [12], Immanuel Wallerstein [13], Samir Amin [14] and Giovanni Arrighi [15] in the 1970s.

When economic structure- and system-forming factors become dominant in the process of globalization, it is necessary to consider a linear approach to the process modeling. The main characteristic of the linear model of globalization is the intensification of international integration without radical changes in its essence. In other words, humankind is "linear", i.e. extensively accumulates the integration potential, contributes to the formation of modern features and strives to overcome contradictions associated with the disunity of peoples.

It should be noted that the extensive accumulation of positive features is an objective process that goes along with the accumulation of negative features, including uncontrolled population growth, socioeconomic and cultural underdevelopment of many countries, educational problems, unsupervised urbanization, the backwardness of health care systems and numerous virus mutations, unresolved food problems, the reduction of non-renewable resources, threats of war, and the aggravation of world terrorism.

The authors of the article aim to optimize further in-depth surveys of the process under consideration with regard to opportunities, forms, methods and tools for systematizing and controlling impacts. Therefore, they need to provide a classification of globalization based on methodological features of a system. The classification developed by the authors includes three main components: 1) absolutely dominant; 2) dominant-conditioned; 3) consensual.

According to the above-mentioned classification, the first component is characterized by a number of distinctive features, namely:

- No unified system of international legal regulation determining the certain status of actors and its internationally sanctioned guarantees;

- One or more absolute leaders in the military sphere, the socalled centers of power, that defend the interests of parties with the most developed military component;

- Specific definition of influence spheres and constant conflicts for their redistribution;
- Conflict-driven resolution of international contradictions and the highest degree of militarization in all spheres of life typical of actors that value even relative sovereignty;

- System of ideological justifications for the objectively unequal position of actors and the inevitability of subordination. These ideological messages are frankly aggressive, pseudoscientific and sometimes anti-human.

This component is typical of colonialism from the commercial expansion between the $15^{\text {th }}$ and $16^{\text {th }}$ centuries and to the industrial expansion of the $19^{\text {th }}$ century. In the second half of the $20^{\text {th }}$ century, this model was replaced with a new one due to international relations based on progressively liberal values and caused by a series of planet-scale catastrophes.

The new dominant-conditioned model is characterized by comparative progressiveness and is based on the declaration of legal equality, the actual state of subordination, functional and ideological dependence. In this regard, all states are divided into leading and subordinate. Under certain circumstances, this state of affairs enables to restore the previous model. Such threats create conditions for folding, rooting and absolutizing block policies as a system of collective protective measures that, in turn, change the notion of sovereignty and its legal characteristics and guarantees. The main characteristics of this model are as follows:

- Legal confirmation of liberal values in declaratory norms;

- Establishment of system measures that confirm the actual inequality of partners, dividing them into "senior" and "junior";

- Determined by the previous feature, the status hierarchy of interests and forms of their achievement creates the so-called "system of double standards";

- This provision triggers the search for the alternative definition and realization of justice, which increase ideological risks, the threat of terrorism and regional conflicts;

- Dominant block ideology causes another system of risks, including the globalization of different local conflicts and their transformation into military forms without individualization of historical international responsibility;

- Polarization of all phenomena characterized by international legal features, alongside with the absolutization of subjective interests of the identified centers of the above-mentioned process. One should keep in mind the compulsory and non-alternative strive of leaders to unipolarity. At the same time, the system of conditions is multidimensional and diverse.

Finally, the name of the third model defines the process paradigm. The authors believe that this model is still under formation and needs to distinguish its typical features. However, this new paradigm is certainly an alternative to the outdated and discredited previous model. Humanistic characteristics and international rational perspectives are in demand from the historical viewpoint and have logically conditioned forms. The authors highlight the following features:

- Recognized and sovereign will of all actors of international relations with the unconditional supremacy of international legal regulators of an absolutely consensual nature;

- Reliable and real form of international legal guarantees with a unified, parity and formally fixed system of sanctions;

- Actual exclusion of the military component from the list of regulatory acts concerned with conflict situations;

- Available police response models with the stated level of force impacts based on the direct consensual decision of all members of any given community;

- Non-proliferation of regulatory standards outside their corresponding community;

- Open and public functioning of all institutional units of any given community;

- Objectives of any given community as an organization concerned with its existence and functioning should not be distinguished depending on the actor's development;

Most of the characteristics listed above were quite prominent in the earlier model but their implementation resulted in the contra- 
diction between leaders' interests and actors' ideas of formal equality.

\section{Discussion}

The authors of the article should emphasize the following notions: Any system aims to enlarge, and this process forms the so-called centers consisting of the most viable elements, i.e. the most developed states (within the framework of the problem under consideration). The adoption of the most successful models leads to the acquisition of typical forms and preferred interaction in order to become a part of some successful activity unless it is a military or violent operation.

The objective nature of globalization is confirmed by the historical existence and development of humankind. One should keep in mind that the forms of this process change at different historical stages under the influence of ideological determinants and their correlating economic factors. The latter can also determine the political and military component of a dominant ideology.

In addition, the existence and functioning of any system are affected by two opposite tendencies: centripetal and centrifugal. As soon as the integration potential is exhausted, centrifugal processes begin to intensify, which ultimately leads to the system disintegration and its extinction. The authors of the article believe the most relevant and important task is to develop methods for assessing prospective integration potentials of countries that can turn into consolidating centers.

\section{Conclusion}

The authors of the article should emphasize the main results achieved while conducting this research.

Having considered various approaches to the classification of globalization processes, the authors suggest the following typology of globalization: 1) absolutely dominant; 2) dominantconditioned; 3) consensual.

The provided classification supports further studies of globalization, including methodological issues of this complex phenomenon.

One should keep in mind that preliminarily determined characteristics aim to rehabilitate the idea of globalism by preserving the elements that have degraded in the previous model. The historical experience objectively requires moving from declaration to the creation of a real implementation mechanism, which is a progressive idea of unifying the value scale of global integration processes.

However, globalization processes are evolutionary in many aspects, the rapid development of these processes in other spheres can be of a quantitative nature, which negatively affects the quality of integration ties.

The authors of the article believe that the problems under study are extremely complicated since the phenomenon of globalization is multidimensional and, naturally, requires further research from various scientific perspectives - from jurisprudence and psychology to economics and geopolitics.

\section{References}

[1] Tikhomirov YuA (2002), Globalizatsiya: Vzaimovliyanie vnutrennego i mezhdunarodnogo prava [Globalization: the mutual influence of inner and international law]. Zhurnal rossiiskogo prava, 11, pp: $3-12$.

[2] Seidov AV (2004), Vozdeistvie globalizatsii na kontseptsiyu gosudarstvennogo suvereniteta $v$ mezhdunarodnom prave [The influence of globalization on the concept of state sovereignty in international law]: Extended abstract of dissertation for a Candidate Degree in Law Sciences. Moscow.

[3] Andreev AL (2017), Globalnyi mir i etnicheskaya revolyutsiya [Global world and ethnic revolution]. Monitoring obshchestven- nogo mneniya: ekonomicheskie i sotsialnye peremeny, 4(140), pp: 23-36, doi: 10.14515/monitoring.2017.4.03.

[4] Sklair L (2001), Transnational capitalist class. John Wiley \& Sons, Ltd., $145 \mathrm{p}$.

[5] Fortune Global500, available online: http://fortune.com/global500/, last visit: 30.10 .2018

[6] Nersesyants VS (1999), Obshchaya teoriya prava i gosudarstva [The general theory of law and state]: Student's book for juridical universities and faculties. Moscow, Norma, $552 \mathrm{p}$.

[7] Nersesyants VS (2005), Protsessy universalizatsii prava i gosudarstva $\mathrm{v}$ globalnom mire [The universalization of law and state in a global world]. Gosudarstvo i pravo, 5 , pp: 40.

[8] Blishchenko VI (eds) (2004), Moscow Legal Forum "Globalization, state, law, the 21st century": forum proceedings. Moscow, Gorodets-izdat, $240 \mathrm{p}$

[9] Klyukovskaya IN, Demchenko TI, Gabrilyan RR, Kardanova AK, Popova LA (2017), Legal Conflicts Resolution in Customary Law of Peoples of the World. Man in India, 97(22), pp: 243-258.

[10] Marochkin SB (1998), Deistvie norm mezhdunarodnogo prava $v$ pravovoi sisteme Rossiiskom Federatsii [Functioning of international law norms in the legal system of the Russian Federation]: Extended abstract of dissertation for a Doctor Degree in Law Sciences Yekaterinburg.

[11] Tveryakova EA (2002), Yuridicheskaya ekspansiya: teoretikoistoricheskoe issledovanie [Juridical expansion: theoretical and historical research]: Extended abstract of dissertation for a Candidate Degree in Law Sciences. Nizhny Novgorod.

[12] Frank AG (1979), Dependent Accumulation. NYU Press.

[13] Hopkins TK, Wallerstein IM (1982), World-systems analysis: theory and methodology (Vol. 1). Sage Publications Inc.

[14] Samir A (1976), L'impérialisme et le développement inégal. Paris, Édition de Minuit.

[15] Arrighi G, Hopkins TK, Wallerstein IM, Vecchi B (1989), Antisystemic movements. London: Verso. 